\title{
Obstructed Defecation Syndrome
}

\section{Outlet Obstrüksiyonu Sendromu}

\author{
(i) Asiye Perek, ๑ Sefa Ergün \\ İstanbul University-Cerrahpaşa, Cerrahpaşa Faculty of Medicine, Department of General Surgery, İstanbul, Turkey
}

\section{IIIIIIII| ABSTRACT}

Chronic constipation is a common problem affecting about $2-30 \%$ of population in the western societies. About $30-50 \%$ of the constipated patients suffer from obstructed defecation. Contrary to colonic constipation stool reaches the rectum, but he or she feels a blocage and is unable to propel the stool. It has two subtypes; mechanical and functional. The functional type is also known as pelvic floor dyssynergy, anismus, spastic pelvic floor, descending perineal syndrome. Mechanical type includes rectocele, enterocel, pelvic organ prolapsus, intussusception, rectal prolapse. Here we attempted to discuss the structures responsible for defecation, etiology, diagnosis and treatment of outlet obstruction.

Keywords: Konstipation, obstructe defecation, pelvic floor diseases, rectocele

\section{||||||||||| ÖZ}

Kronik konstipasyon batı toplumlarında nüfusun \%2-30 kadarını etkileyen yaygın bir şikayettir. Bu hastaların yaklaşı \%30-50 kadarında obstrükte defekasyon-outlet obstrüksiyonu söz konusudur. Bu sendromda kolonik kabızlığın aksine feçes rektuma ulaşır fakat kişi bunu çıkarmakta zorlanır. Obstrükte defekasyon iki alt grupta incelenir: mekanik ve fonksiyonel. Fonksiyonel obstrüksiyon pelvik taban dissinerjisi, anismus, spastik pelvik taban, desendan perine sendromu gibi pekçok isimle anılır. Mekanik tipte rektosel, enterosel, intususepsiyon, pelvik organ prolapsusu, rektal prolapsus gibi mekanik nedenler sözkonusudur. Bu yazıda normal defekasyon mekanizmasından sorumlu yapıları, outlet obstrüksiyon sendromunun etiyoloji, tanı ve tedavisini vermek istedik.

Anahtar Kelimeler: Konstipasyon, obstrükte defekasyon, pelvik taban hastalıkları, rektosel

\section{Introduction}

Chronic constipation is a common problem affecting $2-30 \%$ of the population in Western societies. Of constipated patients 30-50\% have "obstructed defecation syndrome" (ODS). In these patients, removing the stool reaching the rectum is a problem. There are two types of ODS: Functional and mechanical.

In recent years, various pathophysiological processes involved in functional gastrointestinal disorders have been identified: Imbalance in the bacterial flora of the gut, increased intestinal permeability, immune deficiency, neural and hormonal interaction between the brain and the gut. For this reason, the term "bowel-brain interaction disorder" was suggested. ${ }^{1,2}$

\section{Definition}

ODS is the inability of the pelvic floor muscles, especially the puborectal (PR) muscle, to relax during straining, and even paradoxically contracting the anarectal angle (ARA) further narrowing the ARA -like a flap valve- and preventing the passage of stool.

It causes symptoms such as excessive straining, pain, feeling of frequent defecation but unsuccessful defecation, incomplete emptying, small pieces of defecation or hard and thick stools, a feeling of rectal fullness. Since the patient

Address for Correspondence/Yazışma Adresi: Asiye Perek, MD,

İstanbul University-Cerrahpaşa, Cerrahpaşa Faculty of Medicine, Department of General Surgery, İstanbul, Turkey

E-mail: aperek@istanbul.edu.tr ORCID ID: orcid.org/0000-0002-7850-7982

口. Received/Geliş Tarihi: 07.12.2020 Accepted/Kabul Tarihi: 13.12.2020

${ }^{\circ}$ Copyright 2021 by Turkish Society of Colon and Rectal Surgery

Turkish Journal of Colorectal Disease published by Galenos Publishing House. 
is unable to push the stool completely, he/she may feel tenesmus or pelvic fullness, have urgent defecation, need positioning, need enema, and press to the perineum or need digital disimpaction. The patient defecates less than 3 per week.

The anatomical and physiological problems that lead to this syndrome are not fully understood. It includes all pelvic floor anomalies that cause incomplete evacuation of feces from the rectum. Delivery and conditions that cause continuous and recurrent increase in abdominal pressure (obesity, chronic cough, excessive straining) may cause nerve damage by causing excessive stretching of the pelvic floor. ODS may be due to anatomical changes (rectocele, enterocele) or functional disorders [paradoxical puborectal (PR) contraction]. It is often associated with rectocele or rectal intussusception. Rectocele or rectal prolapse can be treated surgically. However, rectal hyposensitivity affects the results of the surgery. When there is rectal sensory impairment, the problem is not solved after subtotal colectomy - ileorectal anastomosis. Today, psychological tension is thought to negatively affect bowel functions. Especially in functional disorders, sexual abuse should also be questioned.

\section{Effective Structures in Defecation Mechanism}

\section{Defecation Muscles}

External anal sphincter (EAS), internal anal sphincter (IAS), PR muscle, levator ani, longitudinal muscle.

\section{Importance of the Puborectal Muscle}

In normal defecation, PR muscle relaxes, the rectoanal angle is flattened, and the stool passes into the anal canal. Failure of the PR muscle to relax leads to functional outlet obstruction. In both sexes, it gives fibers to the external urethral sphincter and the deep part of the EAS. It also gives fibers to the vaginal sphincter and prostatic sphincter.

\section{Levator Tunnel}

The levator tunnel is a tube consisting of the intrahiatal organs - the anal canal, the prostate in men, the vagina in women, and the muscle surrounding the urethra, extending from the levator hiatus to the perineum. The back of the tunnel is longer than the front. The back is $3-4 \mathrm{~cm}$ and the front is $2.5-3 \mathrm{~cm}$ in lenght. This tunnel has two layers which are both striated muscles: Inner suspensory ring and outer PR muscle. The inner ring is relaxant and opens the anal canal at defecation. The outer muscle is constrictor.

\section{Hiatal Ligament}

Levators are connected to the intrahiatal organs by a fascia called the hiatal ligament. It starts from the inner edge of the levators, divides into multiple fanlike septa and attaches to the upper part of the anal canal, bladder neck, and upper part of the vagina. It makes the puboprostatic and pubovesical ligaments in front. It provides harmony between the levator and organs in defecation and micturition. Prolapse develops in the weakness of this ligament.

\section{Rectal Hyposensitivity}

Rectal hyposensitivity is the inability to detect rectal distension, which can be diagnosed during anorectal (AR) physiology tests. It is common in functional outlet obstructions, and there may also be fecal incontinence. It is usually determined by the increased threshold volume during the balloon removal test. It is not clear whether it is due to impairment in afferent nerve conduction. Although its etiology is not well known, there are findings indicating that it is caused by pelvic nerve damage and wrong toilet habits.

\section{Defecation Mechanism}

When stool enters the rectum, reflex contraction and loosening of IAS occur. For defecation, relaxation of the EAS and straining is required. The pushing is necessary to increase the intra-abdominal pressure. There are two reasons for increased intra-abdominal pressure: The detrusor presses the muscles and leads to levator contraction. The anal canal is not affected because it is below the levator. When the levators contract, their funnel shape flattens, they rise and are pulled laterally. This pulls on the hiatal ligament, which opens the AR junction and expands the ARA. Simultaneously, the suspensory ring and longitudinal muscle contract and further expand the ARA.

\section{Assessment of Constipation}

Constipation is often used to describe difficult, prolonged defecation or difficulty in evacuating a small amount of hard stool. The patient may have other symptoms such as bloating, nausea, and pelvic pain. Therefore, objective scoring systems were developed depending on the patient's complaints. ${ }^{3,4}$ (Tables 1, 2, 3, 4)

Tests

- Clinical evaluation

- GITT (Gastrointestinal transit time)

- Colonoscopy

- Defecography

- Colposistography

- Anal manometry

- Balloon push test

- Electromyography - measurement of pudendal nerve conduction

- Endorectal ultrasound (ERUS)

- Dynamic magnetic resonance imaging 
Table 1. Wexner classification (Cleveland Clinic Florida Constipation Scoring)

Number of defecations
1 -2 times in 1-2 days
2 in a week
Once a week
$<1$ per week
$<1$ per month

\section{Painful difficulty in evacuation of stool}

Never

Rarely

Sometimes

Usually

Always

Feeling of incomplete evacuation of stool

Never

Rarely

Sometimes

Usually

Always

Pain-abdominal pain

Never

Rarely

Sometimes

Usually

\section{Score}

0

1

2

3

4

3

0
1
2
3
4

0

0

1

2

3

4

0
1
2
3

Table 1. contiuned

Always

4

Time spent on the toilet (minutes)

$<5$

5-10

10-20

20-30

$>30$

0

1

2

3

4

\section{Help-type}

Unaided

0

Stimulant laxative

Digital disimpaction or using enema

2

Failed defecation attempt in 24 hours

Never

0

1-3

3-6

6-9

$>9$

Constipation time (years)

0

0

$1-5$

5-10

$10-20$

$>20$

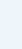

(2)

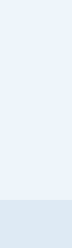

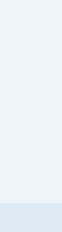

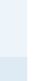

Table 2. Modified Longo classification

\begin{tabular}{|c|c|c|c|c|c|}
\hline Score & Question & Never & $<1$ per week & 1-6 per week & Everyday \\
\hline 1 & Medication for defecation (enema, laxative, etc.) & 0 & 1 & 2 & 3 \\
\hline 2 & Difficulty evacuating & 0 & 1 & 2 & 3 \\
\hline 3 & Digital disimpaction, pressing & 0 & 1 & 2 & 3 \\
\hline 4 & Going to the toilet again & 0 & 1 & 2 & 3 \\
\hline 5 & Feeling of incomplete evacuation & 0 & 1 & 2 & 3 \\
\hline 6 & Pushing for evacuation & 0 & 1 & 2 & 3 \\
\hline 7 & Long time to evacuate & $\begin{array}{l}0 \\
<5 \mathrm{~min}\end{array}$ & $\begin{array}{l}1 \\
6-10 \mathrm{~min}\end{array}$ & $\begin{array}{l}2 \\
11-20 \mathrm{~min}\end{array}$ & $\begin{array}{l}3 \\
>20 \mathrm{~min}\end{array}$ \\
\hline 8 & Affecting the life & 0 (none) & 1 (mild) & 2 (moderate) & 3 (severe) \\
\hline
\end{tabular}

\section{Examination}

Anocutaneous reflex, stool and its consistency in the anus, hemorrhoids, fissure, prolapse, invagination, rectocele are checked. It is evaluated whether there is anal tone, clenching, anorectal mass and fecaloma. During defecation, the parodoxal contraction of the pelvic floor can be evaluated by palpation of the PR muscle with digital rectal examination while the patient is straining. Descending of perineum, mucous discharge, and mucous prolapse may be observed during straining. 
Table 3. Renzi scoring

\begin{tabular}{|c|c|c|c|c|c|}
\hline Symptom & Never & Rarely & Sometimes & Usually & Always \\
\hline Overstrain & 0 & 1 & 2 & 3 & 4 \\
\hline Feeling of incomplete evacuation & 0 & 1 & 2 & 3 & 4 \\
\hline Use of enemas, laxatives & 0 & 1 & 2 & 3 & 4 \\
\hline Suppression from the vagina, perineum & 0 & 1 & 2 & 3 & 4 \\
\hline Abdominal discomfort, pain & 0 & 1 & 2 & 3 & 4 \\
\hline
\end{tabular}

Table 4. Altomare scoring

\begin{tabular}{|c|c|c|c|c|c|}
\hline Score & 0 & 1 & 2 & 3 & 4 \\
\hline Number of defecation attempts per day & 1 & 2 & $3-4$ & $5-6$ & $>6$ \\
\hline Perianal, anal, vaginal suppression & Never & $>1$ month & $<$ l week & 1 per week & Every day in a week \\
\hline Use of laxatives & Never & $>1$ month & $<$ l week & 1 per week & Every day in a week \\
\hline Insufficient, repeated defecation & Never & $>1$ month & $<1$ week & 1 per week & Every day in a week \\
\hline Straining at defecation & Never & $<25 \%$ & $<50 \%$ & $<75 \%$ & $100 \%$ \\
\hline Stool consistency & Soft & Solid & $\begin{array}{l}\text { Solid and little in } \\
\text { amount }\end{array}$ & $\begin{array}{l}\text { Development of } \\
\text { fecaloma }\end{array}$ & \\
\hline
\end{tabular}

\section{Gastrointestinal Transition Time-Colon Transition Time}

Twenty radiopaque markers or isotopically labeled solid fragments are swallowed. It is evaluated with abdominal radiography on 1,3 , and 5 days. Markers are seen in the entire colon even after a week in those with a long transition period. In patients with ODS, markers are seen in the distal colon or rectum.

\section{Defecography}

The patient drinks $150 \mathrm{~mL}$ of diluted barium solution (for small intestine imaging) $45 \mathrm{~min}$ before the procedure. Barium mixed with potato starch or methylcellulose is introduced into the rectum in a normal stool consistency. There is no consensus about the amount $(120-300 \mathrm{~mL})$. Images of the rectum are taken laterally at rest, at straining and at maximum squeezing. Then the patient is asked to evacuate his/her rectum. By giving contrast to the bladder and vagina, pelvic organs can be fully evaluated (Dynamic cystoproctography).

\section{Interpretation}

Rest: The anal canal is closed. The pelvic floor is determined according to the pubococcygeal line (the line drawn from the lower edge of the symphysis pubis to the sacrococcygeal junction). Perineal prolapse is measured from this line to the AR junction. The AR junction, the line drawn between ischial tuberosity and the tip of the coccyx are used as steady points. The caudal displacement of the AR junction is interpreted as the rise or fall of the pelvic floor. It is up to $1.8 \mathrm{~cm}$ at rest. It is less in young people and more in older people. Prolapsing up to $3 \mathrm{~cm}$ from the resting level during defecation is considered normal.

The ARA is the angle between the anal canal axis and the posterior rectal wall parallel to the longitudinal axis of the rectum. It is about 90 degrees, but wider angles, especially in males, may be normal. PR muscle compression is evident at rest. PR length is determined by measuring the distance between ARA and symphysis pubis. ARA is an indirect sign of PR activity. When the muscle contracts, the angle narrows and when it relaxes it expands.

Evacuation: It provides important information about the rectal structure and function. There are 5 elements in normal proctography:

- Increase in ARA

- Deletion of the PR compression

- Opening of the anal canal

- Evacuation of rectal contents

- No significant prolapsing in the pelvic floor

In a normal person, the anal canal should be fully opened within a few seconds, evacuation should begin immediately 
and be complete. ARA increases by 20-30 degrees and PR length increases by 3-4 $\mathrm{cm}$.

Recovery: After evacuation, the anal canal closes, ARA and pelvic floor return to their original state.

The second evaluation parameter is the displacement of the AR junction at straining. Normally; PR ring compression occurs on the posterior wall of the rectum, and the angle of up to $90^{\circ}$ at rest narrows to $75^{\circ}$ in voluntary squeezing, and the AR junction rises. PR ring compression disappears, pelvic floor descends approximately $3.5 \mathrm{~cm}$. At defecation, the PR ring compression disappears completely and ARA increases.

It shows rectoanal invagination.

\section{MR Defecography}

It has the capacity to create multiplan images. Anal canal, ARA, levator muscles, vagina, and their status with respect to the pubo-coccygeal line can be evaluated very well. Compression of the PR muscle to collapse the rectum, excessively narrow AR angle and prolonged evacuation of the rectum are signs of pelvic dysynergy. Perirectal soft tissues cannot be evaluated in conventional defecography. MR defecography provides useful information in this respect. ${ }^{6}$

\section{Dynamic Transperineal Ultrasound}

A simple and inexpensive method that dynamically evaluates the pelvic floor in the anterior, middle and posterior regions.

\section{Colposistography}

Defecography + voiding cystography + vaginal opacification and pelvicography.

\section{Anorectal Manometry}

It is performed to determine motor and sensory abnormalities of the anorectum. While the patient is trying to defecate, 4 types of pressure changes are observed. Normally, intrarectal pressure increases, PR muscle and sphincter relax. In Type I, pushing (intrarectal pressure $>45 \mathrm{mmHg}$ ) is sufficient but anal pressure is increased. In Type II, pushing (intrarectal pressure $<45 \mathrm{mmHG}$ ) and anal sphincter relaxation are insufficient, contraction of the anal sphincter may be seen. Type III is characterized by increased intrarectal pressure (>45 mmHg) and no or very little anal sphincter relaxation. Type I and Type III are classified as dyssynergic defecation.

\section{Balloon Expulsion Test}

Expulsion of the balloon inflated with 50-100 cc from the rectum. Patients with ODS cannot remove the balloon.

\section{Electromyography}

Tonic activity inhibition of pelvic floor muscles (including PR muscle) is measured in straining and defecation. The patient lies on his/her left side and a needle or wire electrode is inserted into the PR muscle to measure it. In pelvic dyssynergia, increased activity is observed in the PR muscle during straining.

\section{Ultrasonography}

Endoanal, endorectal, dynamic anorectal, transvaginal and dynamic transperineal US can be performed.

\section{Dynamic ERUS}

The distance between the peritoneum and the anal verge is measured at rest, then the difference between the two is measured at straining. The length and thickness of the anal sphincter and PR muscle are measured at rest, voluntary squeezing, and defecation (straining). With voluntary squeezing, the thickness of the sphincter increases while its length decreases. The length of the anal sphincter increases and its thickness decreases in expulsion. The PR muscle relaxes, increases in length and decreases in thickness. The position of the patient and the procedure may give conflicting results.

Although clinically asymptomatic, patients with vaginal delivery, anal surgery or trauma may have sphincter damage. The defect can only be in IAS or EAS, or both. If these defects are not diagnosed, they may lead to incontinence after the procedures for ODS. IAS and submucosa thickness increase in all quadrants in rectal prolapse.

Although there are some differences in the Rome IV criteria compared with Rome III criteria, which is a consensus study for constipation, there are no differences affecting the treatment and clinical management. ${ }^{7}$

The pathogenesis of ODS is still controversial. Two main reasons have been identified:

1.Excessive straining at defecation leads to stress neuropathy, which leads to pelvic floor weakening and prolapse of perineum. Difficult vaginal deliveries are also effective in ODS. There is damage to the pelvic tissue innervation and soft tissue in women who give vaginal delivery. Trauma to the pelvic floor soft tissues can lead to defects in the endopelvic fascia and support tissue. Nerve damage secondary to stretching due to vaginal delivery, chronic and recurrent increase in intra-abdominal pressure, obesity, and chronic cough may be a predisposing factor in ODS. Rectal sensation may also be impaired. It may also occur due to cutting of the lateral ligaments after pelvic surgery rectopexy, hysterectomy, etc

2. In cadaver studies with rectocele and intussusception, an increase in the capacity of the rectal ampulla and thinning or loss of the muscle layer of the anterior rectum have been observed. This has also been demonstrated by transanal and transvaginal US in patients with ODS. 
Inability to relax the anal sphincters or paradoxical contraction of the PR muscle is the most common functional cause. The most common mechanical causes are rectocele, rectal invagination, enterocele, genital prolapse, and descending perineum. Functional ODS is also called as anismus, spastic pelvic floor or pelvic floor dyssynergia. The EAS and PR muscle work paradoxically during defecation. ${ }^{8}$

(Table 5, 6)

\section{Rectocele}

Patients with rectocele may also have gynecological and urological symptoms. Therefore, the patient can be admitted to a urologist, gynecologist or general surgeon whichever symptom is at the forefront. Rectocele can be seen in defecography at a rate of $85 \%$ and intussusception $35 \%$ in asymptomatic women. ${ }^{9}$

Table 5. Etiology of obstructed defecation syndrome

\section{Functional}

Anismus; spastic pelvic floor

Pelvic floor dyssynergia

Hirschprung disease

Chagas disease

Hereditary or acquired

Internal anal sphincter myopathy

Central nervous system lesions

Pharmacological

Psychopathological
It is also called posterior prolapse. The rectal wall protrudes into the vagina from the posterior wall of the vagina with an anteroposterior length of more than $2 \mathrm{~cm}$. This is considered as a defect in the rectovaginal septum. However, there are those who find the anatomical importance and even the existence of the rectovaginal septum controversial. The rectovaginal septum consists of dense collagen and elastic fibers and longitudinal smooth muscle bundles from the longitudinal muscles of the rectum wall. It forms an incomplete wall between the rectum and vagina and is complemented by the perineal body caudally. Laterally, it attaches to the pelvic sidewall. It is seen as a V-shaped hyperechoic layer between vagina and rectum with endoanal ultrasound (EAUS) in normal women. In those with rectocele, the septum is seen as thinned or deleted in the midline. It may be pushed towards the vagina or bagged

Table 6. Pathophysiology of obstructed defecation syndrome

\begin{tabular}{|c|c|}
\hline Mechanism & Cause \\
\hline Mechanical outlet obstruction & $\begin{array}{l}\text { Rectal intussusception } \\
\text { External prolapse } \\
\text { Enterocele }\end{array}$ \\
\hline Spread of pressure & $\begin{array}{l}\text { Rectocele } \\
\text { Descending perineum syndrome } \\
\text { Total rectal prolapse }\end{array}$ \\
\hline Functional outlet obstruction & $\begin{array}{l}\text { Inability of inhibition of the internal anal sphincter } \\
\text { Hirschprung disease, Chagas disease, hereditary diseases } \\
\text { Internal sphincter myopathy } \\
\text { Inability of pelvic floor muscles to relax } \\
\text { Paradoxical puborectal contraction } \\
\text { Medulla spinalis lesions } \\
\text { Multiple sclerosis }\end{array}$ \\
\hline Rectal sensory impairment & $\begin{array}{l}\text { Idiopathic megarectum } \\
\text { Rectal hyposensitivity }\end{array}$ \\
\hline
\end{tabular}

\section{Morphological}

Rectocele

Enterocele, sigmoidocele

Rectal prolapse

Rectal invagination

Descending perineum syndrome

Uterus, vaginal prolapse

Stenosis in the anorectum due to various treatments

Rectal tumors 
during the straining. The efficiency of rectocele diagnosis with dynamic EAUS is $87 \%$. In women with rectocele, ERUS also shows the thickness of the rectal mucosa, defects and irregularities in the muscularis propria, as well as deletion of the rectovaginal septum. It is the most common anatomic change that can be seen with inspection and digital rectal and vaginal examinations in women while straining. They are classified according to their position (low, middle, high), according to their size (small; less than $2 \mathrm{~cm}$, moderate; $2-4$ $\mathrm{cm}$, large; more than $4 \mathrm{~cm}$ ), and according to their level (Type I; protruding to the upper vagina, Type II; extending to the introitus, Type III; extending from the introitus). Another classification is the Baden - Walker classification. This classification is for all pelvic organ prolapses. ${ }^{10}$ According to this:

Stage 0; no prolapse

Stage 1 ; lower border of the prolapsed organ is $1 \mathrm{~cm}$ proximal to the hymen

Stage 2; distal of the prolapsed organ is $1 \mathrm{~cm}$ proximal or distal to the hymen

Stage 3; lower border of prolapsed organ is $<1 \mathrm{~cm}$ proximal or $<2 \mathrm{~cm}$ distal from hymen

Stage 4; distal of the prolapsed organ is $>2 \mathrm{~cm}$ distal from hymen.

However, rectocele may not be the cause of ODS symptoms. Those smaller than $2 \mathrm{~cm}$ are usually asymptomatic. When larger than $3 \mathrm{~cm}$, barium is left in the defecography and if there is no anismus, it can be considered as a cause of ODS. Along with other anatomical changes - occult rectal prolapse, sigmoidocele and anismus can be found. Causes are:

- Aging

- Vaginal delivey (large baby)

- Menopause

Feces accumulates in the rectocele. Rectocele may not impair evacuation, but remaining feces in it causes a feeling of not fully evacuating.

\section{Megarectum}

It is defined as the rectum diameter greater than $6 \mathrm{~cm}$ in the pelvis inlet or a total rectum capacity greater than $450 \mathrm{~mL}$ in manometry.

Primary or secondary megarectum is due to rectal sensory impairment or high compliance.

\section{Hirschprung Disease}

Absence of rectal inhibitory reflex.

\section{Descending Perineum Syndrome}

Perineum prolapsus is usually due to excessive strain and weakening of the perineum muscles and stretching damage of the pudendal nerve. This may be due to obstetric trauma or excessive straining. However, its exact etiology is unknown. The AR angle goes down by more than 3.5 $\mathrm{cm}$ in straining and the angle becomes $130^{\circ}$ or more at rest and $155^{\circ}$ or more in straining. Incontinence is usually seen. Sometimes the anterior rectal wall protrudes into the anal canal, and the overhanging mucosa turns into a plug that blocks the anal canal. But it can also be seen in those with prolapsed incontinence.

Dyskinetic Puborectal Muscle Syndrome (Spastic Pelvic Floor Syndrome)

In defecation, the pelvic floor does not descend and the PR muscle contracts paradoxically. The compression of the PR ring becomes evident. Defecation is prolonged and not complete.

Dynamic US is valuable in diagnosis. Anal sphincters contract and thicken and the ARA cannot expand.

\section{Intussusception and Rectal Prolapse}

Rectal intussusception is the concentric invagination of the rectal wall in straining and defecation. It has different degrees: It is defined as rectal, rectoanal or external. It is classified as:

- Intrarectal prolapse

- Intraanal prolapse

- External -total rectal prolapse

It usually starts $6-8 \mathrm{~cm}$ proximal to the anal canal.

Rectal mucosal prolapse is simply invagination of the rectal mucosa.

It is more common in multiparous women, suggesting pelvic floor injury. Normally, rectal intussusception may be seen to some extent. This is the result of ODS, not the cause. It is found to be related with solitary rectal ulcer.

Depth according to the distance from the anterior wall of the anal canal to the anterior end of the rectocele:

$<2 \mathrm{~cm}$; small

2-4 cm; medium

$>4 \mathrm{~cm}$; large-wide

Minors are normally found in women, frequent in multiparous women.

In defecography, transverse or oblique folding of the rectal wall thicker than $3 \mathrm{~cm}$ is seen in the form of a funnel or ring on straining. Folds thinner than $3 \mathrm{~cm}$ indicate mucosal prolapse and are not critical.

Surgery does not give good results in those with functional impairment. They benefit from biofeedback.

\section{Enterocele-Sigmoidosel}

The peritoneum herniates into the area between the vagina or rectum in the pouch of Douglas along the ventral wall 
of the rectum. The peritoneum lies in the form of a sac. Oral contrast is given so that it can be viewed. The distance between rectum and vagina increases. It can usually be shown at the end of the evacuation, may contain small intestine, sigmoid colon or omentum.

It causes mechanical obstruction. Enterocele is small bowel prolapse. The small intestine shifts downward and pushes the vagina from the top. There should be contrast material in the small intestine and vagina for diagnosis. Small, occult enteroceles can be identified with EAUS. In defecography, the area between the rectum and vagina is enlarged and the intestines fill this area. If there is no radiopaque material in the intestines, the enlargement of this area or the presence of air in this area is an indirect sign.

Causes:

It is especially seen if the vaginal wall is weakened after hysterectomy.

- Advanced age

- Vaginal delivery of overweight babies

- Multiparity

- Obesity

- Menopause

If it causes symptoms or impairs quality of life, it is considered pathological. Enterocele gives a feeling of pelvic fullness and usually does not cause ODS. Sigmoidosel is less common and it can cause ODS. MR imaging is good in the diagnosis of both.

\section{Complications of Enterocele - Rectocele Surgery}

- Pain

- Bleeding

- Infection

- Bladder, uterus injury

- Urinary fistula

- Urinary incontinence

- Vaginal stenosis

\section{Functional Disorders}

There is a large group of patients who cannot completely evacuate the rectum but have no structural defects. It is clinically determined by their inability to push the rectal balloon. This is also called as anismus, spastic pelvic floor syndrome, pelvic floor dyssynergia or paradoxical PR syndrome. It has been shown with electromyogram (EMG) that the pelvic floor muscles do not contract properly during evacuation, but this can normally happen. The innervation of the pelvic floor and the inability to increase the intraabdominal pressure are blamed. In proctography, PR compression is more prominent and anal canal and ARA are narrow. Delay in opening the anal canal and incomplete evacuation are seen in those with ODS. Biofeedback gives good results in these patients.

\section{Medical Treatment}

- Lifestyle changes: Drinking plenty of water and a diet rich in fiber are recommended. Psyllium or its similars (matamusil, benefiber, citrucel) can be given for fiber supplement. The aim is to take 30 grams of fiber per day.

- Laxatives

- Yoga: Relaxation and strengthening of the pelvic floor muscles

- Those with depression and anxiety: Psychotherapy

- Those with ODS and rectal hyposensitivity: Biofeedback

After approximately 6 weeks of medical and biofeedback treatment, ODS is evaluated and further procedures are decided.

- Anismus: Botulinum toxin injection transanally to the PR muscle

- Those with pudendal neuropathy and rectal hyposensitivity: Transanal electro-stimulation, sacral nerve stimulation

\section{Botox Injection}

If conservative methods do not provide benefit in patients with sensitive and painful levator ani and PR muscle in palpation, Botox injection may reduce pain. There are 7 types of botulinum toxin. Their antigenic properties are different. BTX-A binds extracellular glycoprotein structures in presynaptic nerve endings and prevents acetylcholine secretion. Lack of acetylcholine causes neuromuscular blockade and muscle paralysis. It is injected into Levator ani (PR muscle) and EAS, and its effectiveness decreases due to the development of antibodies in repeated injections. ${ }^{11} \mathrm{It}$ should not be done in patients who have injection pain but do not have levator sensitivity on examination.

For anal sphincter and levator ani injection, a finger is inserted into the anus, the needle is advanced $2 \mathrm{~cm}$ intersphincterically and injected. If the anal canal is long, you can go further. Injection is made at 3 and 9 o'clock. For levator ani, the needle is inserted $3-4 \mathrm{~cm}$ lateral to the anal verge (lateral to the EAS) and advanced medially. The levator is fixed with the finger in the anal canal, the tip of the needle is felt with the finger, but the mucosa is not punctured and it is injected. ${ }^{11}$

\section{Biofeedback}

Biofeedback is a method that aims to perceive physiological functions by using tools that provide information about the system, to learn how to change it to improve the problem, and to perform these functions without tools and with perseverance over time. It is based on the understanding that mind is superior to tissue. Thus, the body's responses can be changed. These instruments are; EMG, thermometer, 
electrocardiogram (EKG), photoplethysmography (blood flow measurement with the sensor worn on the finger), electroencephalography (EEG), pneumograph, capnometer, and anal manometer, etc. It can be used to modulate respiratory rate, heart rate or high blood pressure. Anal biofeedback is used in fecal incontinence or functional outlet obstruction. The aim is to strengthen the rectoanal inhibitory reflex, increase rectal sensitivity (the result is evaluated by sensing the balloon in small volumes and contracting the EAS in the balloon expulsion test), and increasing the duration and strength of the EAS contraction. The duration of each session, the interval and how long the sessions will be held, and whether they can be performed at home are controversial. Sessions usually take 30-60 minutes. Generally, manometric controlled anal relaxation and defecation simulated biofeedback that provides muscle coordination are used. In one study, $63 \%$ of patients had an improvement in symptoms after 5 sessions. ${ }^{12}$

\section{Rectal Sensitivity Training}

A balloon is placed in the rectum and inflated until rectal fullness is felt. It saves time for the contraction of the EAS and tries to prevent incontinence. In those with urgent defecation or excessive rectal sensitivity, the aim is to teach to tolerate an increasingly larger volume. The strengthening of EAS is done by measuring with EMG, skin electrodes, manometric pressure, intra-anal EMG or ERUS. During anal muscle exercise, muscle activity or anal canal pressure is measured. A balloon is placed in the rectum, upper anal canal and lower anal canal, and the rectal balloon is inflated to trigger rectoanal inhibitor reflex (RAIR). The aim is to teach the EAS to stretch when RAIR develops.

\section{Sacral Nerve Stimulation}

There are studies showing that it is beneficial in those who do not respond to conservative treatment. ${ }^{13}$

\section{Rectocele Surgery}

- Transanal

- Transabdominal

- Transvaginal

- Combined

The use of synthetic or biological mesh in rectocele repair, especially in transvaginal repairs, has been reported. It can cause erosions. An advantage has not been demonstrated. ${ }^{14}$ In transvaginal repair, endopelvic fascia and levators can be exposed better and the integrity of the rectum wall is intact. Transrectal repair should not be performed in patients with rectocele and incontinence. As the rectum wall is plicated transanally, the anal canal may shorten and IAS may be affected..$^{15}$
In transperineal repair, a transverse incision is made over the bulbocavernous and transvers perineal muscles. The plan between the EAS and vaginal mucosa is dissected. Since sphincteroplasty and levatoraplasty can be performed at the same time, it can be recommended in patients with rectocele and incontinence. ${ }^{16}$

\section{Transanal Surgical Methods}

- Partial incision of the PR muscle: Transanally can be performed if non-surgical methods are unsuccessful. There is high risk of fecal incontinence.

- Delorme surgery (transanal excision): Suitable for patients at risk of postoperative fecal incontinence. Recurrence is high. The operation time is long. Anal sphincter injury, temporary incontinence, and constipation may be seen.

- PPH-STARR: In those with intussusception and hemorrhoids.

- STARR (transanal rectal resection with double stapler): Those with rectocele or internal intussusception.

It removes a full-thickness area from the rectum, strengthens the rectovaginal septum, and the prolapsed rectum removed.

- Contour - transtar: If excess tissue is to be removed.

- Bresler procedure: Transanal repair with endoscopic linear stapler.

- TRREMS procedure: Transanal repair of rectocele with single circular stapler and rectal mucosectomy.

-TST-STARR: Tissue selective treatment.

\section{Bressler Surgery}

Transanally, the lower and upper ends of the rectocele are lifted with a tool in the middle and cut longitudinally with a linear stapler. It is only performed in rectocele and ODS caused by rectocele. ${ }^{17,18}$

\section{Modified Bresler Surgery}

Transanally, the anterior wall of the rectum is lifted with three clamps (usually $1.5-7 \mathrm{~cm}$ proximal to the dentate line, ie to include the upper and lower ends of the rectocele). The removed wall is cut longitudinally with a linear stapler. The stapler line is reinforced with 2-0 vicryl (Bresler process). On the posterior wall, 2,3,4 $\mathrm{cm}$ proximal to the dentate line between 2-10 o'clock, three rows of purse strings passing through the mucosa and submucosa are placed to include half of the wall, and they are cut with a circular stapler. If necessary, sutures are placed on the stapler line with 3-0 vicryl for hemostasis. The rectum is fixed transversely and longitudinally. ${ }^{19}$

\section{STARR}

It is performed in ODS caused by rectal intussusception and prolapse. Prolapsed tissue on the anterior and posterior walls is removed in full thickness with 2 circular staplers. A 
stapler corrects the anterior rectocele and intussusception, if any, and repairs the muscle defect in the anterior wall. The second stapler removes the intussusception at the back. It removes mechanical obstruction with prolapsed tissue, decreases the volume of the rectum, and improves rectum compliance. ${ }^{20}$

About $2 \mathrm{~cm}$ above the dentate line, 3 rows of pürse strings passing through the mucosa, submucosa and muscle layer are placed on the anterior wall at 180 degrees to include the rectocele. The stapler is closed, taking care not to include the back wall of the vagina. The stapler line can be reinforced with $2 / 0$ or $3 / 0$ vicryl. The same is done on the back wall. Although the results are good in the early period in those with rectocele and intussusception, long-term results are controversial. ${ }^{21}$

\section{Stapler resection complications:}

- Bleeding

- Urinary retention

- Puborectal dysynergy

- Recurrent ODS

- Rectal diverticulum

- Stenosis

- Granuloma in the anastomosis area

- Sigmoid volvulus

- Rectovaginal fistula

- Emergency feeling of defecation

- Fecal incontinence

- Pelvic sepsis

It is not applied to those with sphincter weakness.

Removable tissue is limited.

Visualization is difficult. ${ }^{22}$

Finally;

- Rectocele should not be considered pathological when seen in examination or defecography. It is common in healthy women.

- Anatomical findings should be evaluated with the patient's complaints and their effect on quality of life.

- Genital prolapse and enterocele should be evaluated in patients with ODS symptoms.

- Mechanical causes should be ruled out.

- Benefits of diagnostic methods should be fully understood.

- Conservative treatments are important in functional disorders.

Peer-review: Externally and internally peer reviewed.

\section{Authorship Contributions}

Surgical and Medical Practices: A.P., Concept: A.P., Design: A.P., S.E., Data Collection or Processing: A.P., S.E.,
Analysis or Interpretation: A.P., S.E., Literature Search: A.P., S.E., Writing: A.P.

Conflict of Interest: No conflict of interest was declared by the authors.

Financial Disclosure: The authors declared that this study received no financial support.

\section{References}

1. Rashid A, Khuroo S. Obstructed defecation syndrome: a treatise on its functional variant. Intern Med 2014. doi: :10.4172/2165-8048.S1-005

2. Simren M, Palsson OS, Whitehead WE. Update on Rome IV criteria for colorectal disorders: implications for clinical practice. Curr Gastroenterol Rep 2017;19:15

3. Agachan F, Chen T, Pfeifer J, Reissman P, Wexner SDA constipation scoring system to simplify evaluation and management of constipated patients. Dis Colon Rectum 1996;39:681-685.

4. Altomare DF, Spazzafumo L, Rinaldi M, Dodi G, Ghiselli R, Piloni V. Set-up and statistical validation of a new scoring system for obstructed defecation syndrome. Colorectal Dis 2008;10:84-88.

5. Caetano AC, Dias S, Santa-Cruz A, Rolanda C. Renzi score for obstructed defecation syndrome-validation of the portuguese version according to the cosmin checklist. Arq Gastroenterol 2018;55:55-60.

6. 6.Roos, JE, Weishaupt D, Wildermuth S, Willmann JK, Marincek B, Hilfiker PR. Experience of 4 years with open MR defecography: pictorial review of anorectal anatomy and disease. Radiographics 2002;22:817-832.

7. Bharucha AE, Lee, TH. Anorectal and pelvic pain. In mayo clinic proceedings. Philaedelpia: Elsevier Saunders, 2016:1471-1486.

8. Roberts JP, Womack NR, Hallan RI, Thorpe AC, Williams NS. Evidence from dynamic integrated proctography to redefine anismus. Br J Surg 1992;79:1213-1215.

9. Dvorkin LS, Gladman MA, Epstein J, Scott SM, Williams NS, Lunniss PJ. Rectal intussusception in symptomatic patients is different from that in asymptomatic volunteers. Br J Surg 2005;92:866-872.

10. Artibani W, Haab F, Hilton P. Pelvic floor reconstruction. European Urology, 2002;42:I-XI.

11. Ooijevaar RE, Felt-Bersma RJF, Han-Geurts IJ, van Reijn D, Vollebregt $\mathrm{PF}$, Molenaar $\mathrm{CBH}$. Botox treatment in patients with chronic functional anorectal pain: experiences of a tertiary referral proctology clinic. Techn Coloproctol 2019;23:239-244.

12. Chiarioni G, Salandini L, Whitehead WE. Biofeedback benefits only patients with outlet dysfunction, not patients with isolated slow transit constipation. Gastroenterology 2005;129:86-97.

13. Kamm MA, Dudding TC, Melenhorst J, Jarrett M, Wang Z, Buntzen S, Matzel K. Sacral nerve stimulation for intractable constipation. Gut 2010;59:333340 .

14. de Tayrac R, Picone O, Chauvaud-Lambling M, Fernandez H. A 2 year anatomical and functional assesment of transvaginal rectocele repair using a polyprolene mesh. Int Urogynecol J Pelvic Floor Disfunction 2006;17:100-105

15. Ho YH, Ang M, Nyam D, Tan M, Seow-Choen E. Transanal approach to rectocele repair may compromise anal sphincter pressure. Dis Colon Rectum 1998;41:354-358.

16. Nieminen K, Hiltunen KM, Latitinent Oksala J, Heinonen PK. Transanal or vaginal approach to rectocele repair: a prospective randomised pilot study. Dis Colon Rectum 2004;47:1636-1642.

17. de la Portilla F, Rada R, Vega J, Segovia-González MM, Caro F, Cisneros $\mathrm{N}$, Maldonado VH. Transanal rectocele repair using linear stapler and bioabsorbable stapler line enforcement material: short term results of a prospective study. Dis Colon Rectum 2010;53:88-92. 
18. Jiang C, Ding Z, Wang M, Yang G, Situ G, Wu Y, Qian Q. A transanal procedure using an endoscopic linear stapler for obstructed defecation syndrome: the first Chinese experience. Tech Coloproctol 2012;16:21-27.

19. Deng Q, Yu KL, Liu ZY, Shen Z, Wang YH, Song YM, Wang JW. Outcomes of a modified Bresler procedure for the treatment of rectocele with rectal intussusception. Gastroenterol Rep (Oxf) 2020;8:457-464.

20. Ribaric G, D'Hoore A, Schiffhorst G, Hempel E, TRANSTAR Registry Study Group. STARR with CONTOUR® TRANSTARTM device for obstructed defecation syndrome: one-year real-world outcomes of the European TRANSTAR registry. Int J Colorectal Dis 2014;29:611-622.

21. Boccasanta P, Venturi M, Stuto A, Bottini C, Caviglia A, Carriero, A, Landolfi V. Stapled transanal rectal resection for outlet obstruction: a prospective, multicenter trial. Dis Colon Rectum 2004;47:1285-1297.

22. Schiano di Visconte M, Nicoli F, Pasquali A, Bellio G. Clinical outcomes of stapled transanal resection for obstructed defecation syndrone at 10 year fallow-up. Colorectal Dis 2018;20:614-622. 